\title{
MENINGKATKAN KEPEDULIAN SOSIAL MAHASISWA MELALUI PENGABDIAN MASYARAKAT PADA PARA SISWA TAMAN KANAK-KANAK
}

\author{
Merlin Lenniawati ${ }^{1)}$ \\ ${ }^{1}$ Program Studi Manajemen Keuangan, Universitas Kristen Petra \\ Email :d11170132@john.petra.ac.id
}

\begin{abstract}
The feeling of concern and empathy of the millennial generation is very different from the generations before them, this can be proven through the action of these days University Student who can rarely interact with each other in great manner, and of course the lack of respect to the older generation. This happens because of the rapid development of technology and this also concerning because the millennials are the generation that will bring a Nation to its future. Social concern that the millennial generation have will be an example to the kindergarten student because they will look up to them and consider them to be more mature, so to avoid any bad influence for the newer generation a Social Service Program will be held with a purpose to renew the mindset of University Students that there are so many positive things that can be done to plant the feeling of concern and empathy earlier so that they can practice it in real life. The sample of this research is the Kindergarten Student.
\end{abstract}

Key Word: social concern, kindergarten social service

\section{PENDAhuluan}

Indonesia memiliki modal yang besar supaya menjadi bangsa yang memiliki level setara dengan negara-negara lainnya, hal ini bisa sangat mudah terjadi jika seluruh masyarakat Indonesia memiliki tingkat kepedulian yang tinggi. Maka segala sesuatu aktivitas akan bisa berjalan dengan baik adanya, dan pastinya Negara-negara lain juga ingin memiliki hal yang serupa bisa terjadi di negaranya. Secara mendasar dapat dikatakan bahwa kepedulian memegang peranan penting agar setiap aktivitas atau kegiatan dapat berjalan dengan baik adanya dan tidak ada hambatan-hambatan yang timbul karena keegoisan manusia.

Berdasarkan survei penduduk antar sensus (Supas) 2015 jumlah penduduk Indonesia pada 2019 diproyeksikan mencapai 266,91 juta jiwa. Menurut jenis kelamin, jumlah tersebut terdiri atas 134 juta jiwa lakilaki dan 132,89 juta jiwa perempuan.Dapat dilihat dari gambar diatas menunjukkan bahwa Indonesia memiliki penduduk yang sebagian besar merupakan generasi milenial, hal ini sangat berdampak bagi kemajuan bangsa Indonesia dalam sektor perekonomian.

Generasi milenial merupakan generasi yang sangat mudah mempelajari hal baru, khususnya dalam bidang teknologi dan juga memiliki inovasi yang tinggi terhadap segala sesuatu yang ada. Jika kedua hal yang dimiliki oleh generasi milenial ini digabungkan maka generasi milenial dapat menjadi ujung tombak bagi perubahan dan kemajuan bangsa Indonesia. Namun, kemudahan generasi milenial untuk mempelajari hal baru dalam bidang teknologi berdampak negatif yaitu menjadikan generasi milenial sulit memiliki rasa solidaritas karena lebih memilih bersosialisasi melalui gadget, selain itu generasi milenial juga menginginkan segala sesuatunya praktis seperti memesan makan melalui go-jek, dan juga rasa empati dan simpati yang dimiliki oleh generasi milenial berkurang dibandingkan dengan generasi baby boomer. Hal-hal ini dipengaruhi oleh globalisasi, dan juga kemajuan teknologi yang sangat cepat, serta ketidaksiapan masyarakat Indonesia dalam menerima perubahan yang ada. Generasi ini memiliki banyak peluang untuk bisa berada jauh di depan dibanding generasi sebelumnya. Namun sayangnya, generasi milenial cenderung lebih tidak peduli terhadap keadaan sosial, termasuk politik dan ekonomi. Mereka cenderung lebih fokus kepada pola hidup kebebasan dan hedonisme. Mereka cenderung mengingkan 
hal yang instant dan tidak menghargai proses.

Kepedulian yang ditanamkan sejak dini dalam diri seseorang dapat membentuk ataupun mempengaruhi pemikiran yang akan berdampak pada perbuatan dan perkataan. Namun kenyataannya masih banyak generasi milenial yang merupakan mahasiswa yang masih belum memiliki rasa kepedulian yang terwujud dalam perbuataan dan perkataannya, contohnya saja tidak memperbolehkan memfoto atau melihat catatan. Hal ini timbul karena dilatar belakangi oleh peristiwa masa lalu yang beredar seperti banyak mahasiswa yang memfoto catatan mendapatkan nilai lebih bagus dari pada mahasiswa yang mencatat. Contoh lain yaitu masih banyak mahasiswa yang sering berkata kasar jika menghadapi suatu masalah ataupun jika mendengar cerita mengenai teman yang mengalami kesulitan, bahkan tidak sedikit yang mengolok maupun mengejek teman yang sedang dalam kesusahan. Hal ini terjadi karena pengaruh lingkungan yang mempengaruhi kebiasaan tumbuh, kembang seseorang yang akan melekat pada diri orang tersebut.

Kepedulian merupakan hal yang sangat mulia, karena jika kita peduli kepada orang lain maka suatu saat nanti akan ada orang yang peduli dengan kita. Hal ini sama dengan prinsip tabur-tuai ataupun karma. Pada prinsipnya memang kita tidak akan kehilangan sesuatu jika kita berbagai terhadap sesama, maka kita akan mendapatkan berlipat kali ganda sesuai dengan yang kita bagikan.

Kepedulian bisa dilakukan melalui banyak hal seperti, menjenguk jika ada teman yang sedang terkena musibah ataupun penyakit, memberikan dukungan jika teman sedang dalam kesusahan agar tetap berjuang menemukan jalan keluarnya, membantu baik secara keuangan maupun secara fisik, bisa juga memberi makanan ataupun barangbarang yang masih layak pakai kepada sesama yang lebih membutuhkan, memberikan bantuan ilmu kepada sesama yang kurang beruntung, dan juga melalui program pengabdian masyarakat.

Pengabdian masyarakat merupakan salah satu media untuk mengasah kepedulian mahasiswa, dalam menjalankan pengabdian masyarakat. Mahasiswa mempersiapkan banyak materi ajaran yang dilakukan dengan cara bermain bersama siswa taman kanakkanak yang memiliki tujuan pada setiap materinya seperti, mengembangkan unsur seni, mengenalkan huruf, belajar berhitung, mengenalkan mata uang, serta menghargai pendapat orang lain.

Dampak yang diharapkan dari kegiatan ini bagi siswa taman kanak-kanak yaitu mampu memberikan perubahan gaya hidup hemat yang nantinya akan berdampak pada keuangan keluarga, dan juga membangun rasa kepedulian kepada mahasiswa yang merupakan generasi milenial agar lebih terbuka kepada dunia sosial yang masih banyaknya orang-orang yang membutuhkan bantuan ilmu dari orang-orang yang lebih memahami ataupun lebih beruntung daripada mereka.

\section{TINJAUAN PUSTAKA}

Manusia sebagai makhluk sosial adalah makhluk yang memiliki kecenderungan menyukai dan membutuhkan kehadiran sesamanya sebagai kebutuhan dasar yang disebut kebutuhan sosial (social needs)

Kepedulian sosial yaitu sebuah sikap keterhubungan dengan kemanusiaan pada umumnya, sebuah empati bagi setiap anggota komunitas manusia. Kepedulian sosial adalah kondisi alamiah spesies manusia dan perangkat yang mengikat masyarakat secara bersama-sama (Adler, 1927).

Ketrampilan pada awal masa kanakkanak merupakan masa yang ideal untuk mempelajari ketrampilan tertentu, hal ini terdapat tiga alasan yang mendasari yang pertama anak sedang mengulang-ulang suatu aktivitas hingga terampil melakukannya. Kedua, anak-anak masih memiliki sifat pemberani sehingga tidak terhambat oleh rasa takut dan yang ketiga yaitu anak usia dini mudah dan cepat belajar ketrampilan baru. Awal masa kanak-kanak dapat dianggap sebagai saat belajar untuk belajar ketrampilan.

Anak-anak yang berada pada Taman kanak-kanak biasanya terdiri dari usia 4-6 tahun, yang terbagi menjadi 2 kelas yaitu kelas untuk taman kanak-kanak A yang berusia 4-5 tahun, dan taman kanak-kanak B dengan usia 5-6 tahun. Sedangkan untuk mahasiswa biasanya berusia 18-21, untuk jenjang mahasiswa terbagi menjadi 2 bagian yaitu D3 ataupun S1.

Belajar sambil bermain menyatakan 
bahwa permainan secara langsung mempengaruhi seluruh area perkembangan anak dengan memberikan kesempatan bagi anak untuk belajar tentang dirinya, orang lain, dan lingkungannya.

Pengabdian masyarakat adalah pengamalan ilmu pengetahuan, teknologi dan seni langsung kepada masyarakat secara melembaga melalui metodologi ilmiah sebagai tanggungjawab luhur perguruan tinggi dalam usaha mengembangkan kemampuan masyarakat sehingga dapat mempercepat tercapainya tujuan pembangunan nasional. (Slamet,1986)

Video merupakan pengganti alam sekitar dan dapat menunjukkan objek yang secara normal tidak dapat dilihat siswa seperti materi proses pencernaan makanan dan pernafasan, video dapat menggambarkan suatu proses secara tepat dan dapat dilihat secara berulang-ulang, video juga mendorong dan meningkatkan motivasi siswa untuk tetap melihatnya. (Azhar Arsyad, 2011: 49)

\section{METODOLOGI}

Teknik yang digunakan, yaitu Kualitatif dengan menggunakan metode observasi yang dilakukan oleh mahasiswa. Observasi merupakan teknik yang dilakukan untuk mendapatkan data primer dengan cara mengamati perilaku siswa

Taman Kanak-kanak secara langsung. Pengamatan yang kami lakukan sekitar 3 bulan yang dijadwalkan 1-2 kali dalam setiap 1 bulan. Dalam setiap kunjungan selama 1,5 jam hingga 2 jam lamanya dengan waktu yang ada mahasiswa melakukan pengamatan dalam setiap kegiatan yang diadakan. Pengamatannya meliputi sikap, karakterisitik, dan respon dari siswa taman kanak-kanak terhadap aturan contoh dan arahan dari mahasiswa dalam setiap kegiatan yang berlangsung.

Setelah mendapatkan data yang relevan, berikutnya dilakukan analisa terkait kegiatan pengabdian masyarakat dengan menggunakan media pengajaran yang bertujuan untuk memotivasi para siswa taman kanak-kanak. Tolak ukur yang digunakan yaitu melihat kemajuan dalam diri setiap siswa taman kanak-kanak. Hal ini dapat dilihat dari perlakuannya kepada temanteman maupun kepada mahasiswa yang masih tetap sama dengan sebelumnya atau sudah berbeda dan dapat bekerja sama dengan baik.

\section{HASIL DAN PEMBAHASAN}

Kepedulian sosial adalah minat atau ketertarikan kita untuk membantu orang lain. Hilangnya rasa kepedulian tentu saja memberi dampak negatif bagi seluruh lapisan masyarakat. Sikap acuh yang diberikan secara tidak langsung mempengaruhi orangorang disekitar sehingga dapat merugikan bukan hanya satu individu namun juga terhadap masyarakat. Kepedulian dapat mencegah perpecahan, dan dapat memberikan semangat kepada orang lain yang sedang putus-asa, sehingga banyak hal bisa terwujud yang selama ini hanya menjadi angan-angan dalam benak bangsa Indonesia, seperti terwujudnya persatuan dan kesatuan masyarakat Indonesia sesuai dengan pancasila sila ke-3, tidak adanya korupsi, kolusi, dan nepotisme ataupun penyalahgunaan kekuasaan sehingga masyarakat Indonesia bisa memperoleh hak dan kewajibannya secara adil dan merata hingga pelosok Indonesia.

Sikap kepedulian dapat direalisasikan dengan melakukan banyak kegiatan antara lain dengan membantu orang di lingkungan sekitar, menjenguk kerabat, saling gotong royong dalam lingkungan masyarakat, memberi sedekah dan banyak kegiatan pengabdian masyarakat lainnya. Hal ini dilakukan tentu dengan persiapan yang matang, dengan menguras tenaga, pikiran, namun dampaknya akan melebihi dari hanya sekadar kata oleh karena tindakan nyata yang diberikan oleh 1 individu atau kelompok kepada individu atau kelompok lainnya.

Melihat fakta bahwa banyak sekali anak generasi milenial yang tidak memiliki rasa kepedulian kepada sesama, dalam hal-hal yang sederhana maupun hal-hal yang besar, seperti membantu teman yang sedang dalam kesusahaan, memberikan senyum sapa saat bertemu, dan sekedar mengucapkan tolong dan terima kasih. Hal- hal seperti ini sudah sangat sulit ditemukan dalam generasi milenial ini, mereka cenderung untuk asik bermain gadget tanpa melihat lingkungan sekitar dan apa yang terjadi di sekelilingnya.

Salah satu kegiatan yang menjadi saluran rasa kepedulian dalam kalanganmahasiswa yaitu pengabdian masyarakat. Kegiatan ini merupakan sarana 
bagi mahasiswa untuk mengasah rasa kepedulian yang dimiliki. Pengabdian masyarakat dapat dilakukan kepada siapa saja serta memiliki tujuan yang bermanfaat baik secara sosial maupun ekonomi. Pengabdian masyarakat harus dilakukan secara rutin (minimal 3 kali kunjungan), tentunya kegiatan ini harus memiliki latar belakang, tujuan, dan bentuk kegiatan yang sesuai dengan lingkungan dimana kita mengadakannya agar kegiatan ini dapat berdampak nyata bagi peserta, sebagai contohnya kegiatan pengabdian masyarakat yang dapat dilakukan oleh mahasiswa terhadap siswa Taman Kanak-Kanak yang berada di kota Surabaya dengan kondisi ekonomi menengah kebawah yang terkadang kurang mendapatkan perhatian. Orang tua yang baik pasti menginginkan anaknya untuk memiliki kehidupan layak, memiliki kehidupan yang berkecukupan, serta memiliki rasa kepedulian dan empati agar dapat memiliki masa depan yang lebih baik dari pada orang tuanya. Maka orang tua akan berusaha keras mememberikan pengajaran yang cukup dan memadai demi bekal sang anak untuk mencapai kedewasaan.

Kegiatan pengabdian masyarakat merupakan kegiatan yang sesuai dengan namanya yaitu membagikan ilmu kepada masyarakat sebagai wujud nyata bentuk ataupun rasa kepedulian kepada sesama yang nantinya dapat menyejahterakan kehidupan masyarakat, selain itu kegiatan ini memiliki tujuan untuk membentuk seseorang menjadi pribadi yang memiliki karakter kepedulian yang melekat sejak usia dini dan juga memiliki pola pemikiran yang memperhatikan sesamanya, dimana jika hal ini dapat melekat pada anak-anak usia dini maka secara tidak langsung akan mempengaruhi lingkungan sekitarnya dan menciptakan lingkungan yang memiliki rasa kepedulian yang tinggi serta dapat memberikan solusi terhadap tantangan yang ada dalam masyarakat sekitar dan yang terakhir dapat mengembangkan sumber daya manusia agar dapat dihormati sesuai dengan hak dan kewajibannya. Tidak berhenti disini saja, mahasiswa juga memiliki peran yang penting untuk menjadi role model dalam masyarakat agar masyarakat bisa melihat bahwa mahasiswa tidak hanya memiliki otak yang cerdas tapi juga memiliki karakter, sikap, dan akhlak yang mulia.

Kegiatan pengabdian masyarakat dapat dilakukan oleh siapa saja dan dimana saja, namun generasi muda pada era ini memiliki peran yang cukup penting sebagai generasi penerus bangsa yang jumlahnya merupakan sebagian besar dari jumlahpenduduk di Indonesia.

Generasi penerus bangsa khususnya mahasiswa harus memiliki kegiatan ini dengan sarana mengintrospeksikan diri untuk menjadi akan dilaksanakan oleh mahasiswa pada semester genap dalam dunia perkuliahan dengan sasaran siswa taman kanak-kanak yang memiliki latar belakang ekonomi menengah keatas di daerah Surabaya. Kegiatan ini akan dilakukan dengan cara mahasiswa akan berkunjung ke sekolah-sekolah yang cukup ternama di Surabaya yang tentunya memiliki kondisi ekonomi menengah keatas. Jadwal kunjungan untuk setiap sekolah yaitu tiga hingga lima kali dalam dua bulan dengan setiap kali kunjungan selama satu hingga tiga jam.

Kegiatan pengabdian masyarakat ini ditujukan kepada anak-anak dengan ekonomi menengah keatas dikarenakan dengan keadaan ekonomi menengah keatas terkadang membentuk kecenderungan pola perilaku maupun karakter yang menginginkan segala sesuatu dengan mudah dan dapat didapatkan dengan uang, terkadang hal ini dapat melunturkan itikad baik dari seseorang dan hanya menilai orang lain dari segi materi dan mengabaikan hal lain sehingga yang pada akhirnya melupakan integritas. Pola pendidikan maupun perilaku yang diterapkan sejak dini mampu membentuk bagaimana tumbuh kembang serta pola pikir anak-anak hingga bertumbuh dewasa. Siswa - siswa di taman kanak-kanak yang menjadi target peserta memiliki kecenderungan mendapatkan kemudahan untuk mendapatkan apa saja yang mereka inginkan, maka dengan kegiatan pengabdian masyarakat ini dapat melatih rasa kepeduliannya sejak usia dini terhadap orang lain khususnya orang yang lebih tua agar bisa tertanam dalam benak siswa taman kanak-kanak dan tidak bertindak seenaknya sendiri walaupun mereka memiliki latar belakang ekonomi yang jauh lebih cukup. Siswa siswi juga diarahkan untuk akhirnya melakukan usaha 
keras dan kerja sama dalam mencapai sesuatu demi kepentingan kelompok dan bukan hanya untuk kepentingan pribadi.

Peran teknologi juga tidak kalah pentingnya, dimana tidak dapat dibantah bahwa teknologi ikut mempengaruhi pola pikir dan pengetahuan anak terhadap diri sendiri dan dunia luar yang begitu luas, bukan hanya siswa Taman Kanak-Kanak, namun juga Mahasiswa sebagai generasi penerus bangsa. Hal yang akan diajarkan kepada anak-anak adalah dengan adanya teknologi, sebaiknya tidak menjauhkan kehidupan sekitar dan menjadi pemisah antara diri dan dunia luar, namun teknologi dapat membangun relasi serta kerja-sama antara satu individu dengan individu lainnya Dengan tujuan mendorong setiap siswa untuk saling berinteraksi melalui kegiatan belajar sehari-hari dengan kakak mahasiswa, sambil mengasah jiwa seni, mengajak siswa mengeja suku kata hingga membentuk kata dan frasa, membangkitkan minat dan menumbuhkan keinginan untuk berkembang, sertamengajarkan siswa untuk saling peduli dan menyayangi satu dengan yang lain.

Pendekatan dalam pendidikan anak usia dini yaitu bermain sambil belajar. Bermain merupakan pendekatan dalam melaksanakan kegiatan pendidikan usia dini, dengan menggunakan strategi, metode, materi dan media yang menarik agar mudah diikuti oleh anak. Melalui bermain anak diajak untuk bereksplorasi, menemukan, memanfaatkan dan mengambil kesimpulan mengenai benda di sekitarnya, serta dapat membantu anak mengenal tentang diri sendiri beserta lingkungannya. Bermain sendiri merupakan kebutuhan bagi anak, melalui bermain anak akan memperoleh pengetahuan.

Peserta dalam kegiatan pengabdian masyarakat ini juga dilihat melalui umurnya karena jika terlalu kecil maka belum tentu bisa mengerti apa yang disampaikan, maka kegiatan ini ditetapkan pada siswa taman kanak-kanak dengan usia 5-6 tahun, berkisar 10-20 orang yang lebih didominasi oleh laki-laki. Dari Mahasiswa berjumlah 4 orang yang lebh didominasi oleh wanita, dengan komposisi yang seperti ini maka diharapkan kegiatan dapat berjalan dengan baik dan lancar. Hal ini dikarenakan wanita lebih sabar dan memiliki jiwa ke-ibuan dibandingkan laki-laki, sehingga bisa mengenali situasi dan kondisi yang ada selama kegiatan berlangsung. Dalam kegiatan ini setiap sesi kegiatan akan dipimpin oleh satu orang mahasiswa dan dibantu oleh ketiga mahasiswa lainnya untuk mengarahkan siswa taman kanakkanak fokus pada materi yang disampaikan, tidak hanya arahan dari mahasiswa namun juga menggunakan media yang bisa menarik perhatian siswa taman kanak-kanak agar terus mendengarkan dan memahami maksud dari materi tersbut. Manfaat yang didapatkan jika kegiatan pengabdian masyarakat ini dilakuan dengan menggunakan media adalah materi yang disampaikan dapat diterima oleh peserta secara efektif dan efisien baik secara waktu maupun tenaga.

Media yang digunakan dalam pengabdian masyarakat bagi siswa taman kanak- kanak berupa media yang mampu mengestimasi timbulnya rasa kepedulian satu dengan yang lain serta menumbuhkan rasa ingin tahu terhadap seni dan teknologi pada jiwa siswa taman kanak-kanak, sehingga kegiatan ini dapat berjalan dengan baik. Media yang dapat digunakan pada kegiatan pengabdian masyarakat ini dapat dituangkan melalui kegiatan bersama sehingga memerlukan kerja sama antara siswa Taman Kanak-Kanak yang sudah dipersiapkan oleh Mahasiswa, hal ini tentu saja mewujudkan interaksi antara sesama siswa dan juga dengan Mahasiswa sebagai fasilitator dalam kegiatan tersebut. Aktivitas yang dilakukan dapat merangsang kemampuan anak untuk memecahkan masalah yang sederhana dan membantu satu sama lain agar mencapai tujuan yang sama. Sembari melakukan kegiatan tersebut, Mahasiswa dapat mendokumentasikan kegiatan dan membuat film pendek bersama siswa taman kanak-kanak sebagai pemeran yang berisikan aktivitas anak-anak serta interaksi dengan sesama yang nantinya akan diputar pada akhir kegiatan.

Berikut merupakan beberapa contoh media yang dapat digunakan dalam kegiatan pengabdian masyarakat yang dapat membantu menyampaikan materi yang diberikan dengan metode belajar sambil bermain: 


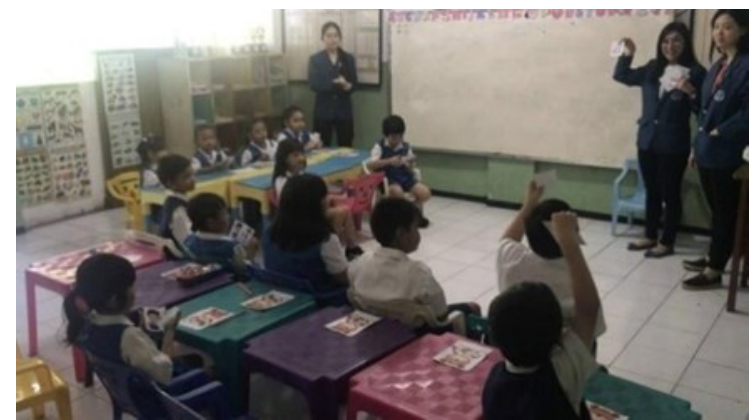

Gambar 2. Kartu kembar

Dalam kegiatan ini mahasiswa membagikan kartu kepada siswa taman kanak-kanak, kartu yang dibagikan ini terdapat gambar yang bermacam- macam mulai dari merapikan tempat tidur, mencuci tangan, merapikan mainan dan lainnya. Kerjasama yang baik dilakukan oleh siswasiswa taman kanak- kanak terhadap mahasiswa dan keberhasilan penyampaian informasi dari mahasiswa kepada siswa taman kanak-kanak sehingga kegiatan dapat berjalann dengan baik. Kegiatan ini memiliki tujuan untuk melatih fokus siswa taman kanak-kanak dengan media gambar yang bisa membantu menanamkan dalam pola pikir kepedulian siswa taman kanak-kanak.

Siswa taman kanak-kanak merespon dengan sangat baik ketika kegiatan ini berlangsung, hal ini ditandai dengan kontribusi aktif dari setiap siswa taman kanak-kanak yang merespon kegiatan ini dengan suara yang kencang serta konsentrasi dari setiap siswa taman kanak-kanak yang sangat terfokus pada salah satu mahasiswa yang memimpin kegiatan ini dan siswa taman kanak- kanak juga mengingat betul apa gambar yang dimiliki agar nantinya bisa mencocokkan kartu yang akan dibuka oleh mahasiswa. Tidak berhenti hanya dari responnya saja namun siswa taman kanakkanak juga tidak menginginkan kegiatan ini berhenti walaupun kartu yang dimiliki sudah habis, salah satu diantara siswa tersebut meminta kepada mahasiswa untuk membagikan kartu yang dimiliki mahasiswa kepada siswa-siswi taman kanak-kanak.

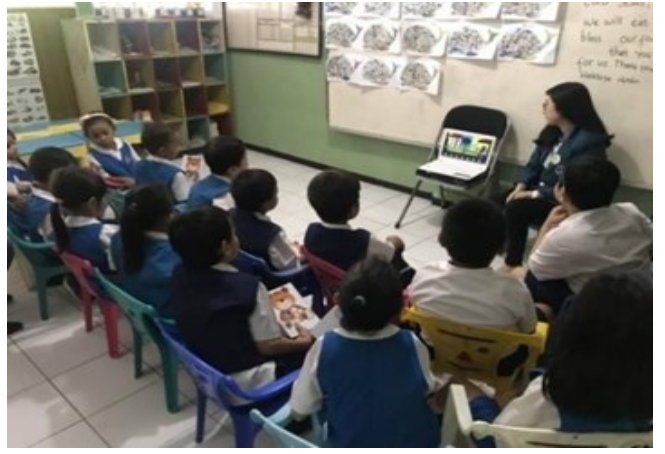

Gambar 3. Menonton video

Menonton video merupakan salah satu aktifitas kesukaan bagi anak-anak usia dini selain menjadi kesukaan yang merupakan sarana bermain, hal ini dapat dimanfaatkan menjadi sarana pembalajaran serta memiliki visualisasi yang mudah dipahami dan tertanam dalam pikiran anak-anak usia dini. Media video ini dipilih karena menampilkan karakter tokoh yang dapat menarik siswa taman kanak-kanak dan juga secara tidak langsung siswa taman kanakkanak bisa langsung mengingat apa yang dilakukan karakter tersebut dan diharapkan dapat diwujud nyatakan pada kehidupannya sehari- hari. Kegiatan menonton video ini berlangsung cukup lama dikarenakan banyak siswa taman kanak-kanak yang sangat fokus melihat video dan meminta untuk melihatnya secara berulang-ulang, hal ini memang mengakibatkan 2 hal yaitu sisi baik bagi siswa taman kanak-kanak karena bisa melihat suatu kejadian secara berulang yang nantinya akan membekas dalam pikiran mereka dan juga yang kedua merupakan sisi negative karena waktu yang ditargetkan melebihi dan berdampak pada kegiatan berikutnya. Namun hal ini teratasi dengan baik karena siswa taman kanakkanak bisa mengerti dan peduli kepada mahasiswa dan melanjutkan pada kegiatan selanjutnya.

Persiapan yang dilakukan untuk menyiapkan kegiatan menonton video yaitu mencari film yang sesuai dengan tema lalu mendownload film tersebut, untuk memilih film harus benar-benar memberikan film yang berbobot dan sesuai dengan makna dari kegiatan yang ingin disampaikan agar kegiatan ini dapat berjalan dengan baik dan juga memberikan manfaat kepada siswa taman kanak- kanak. 


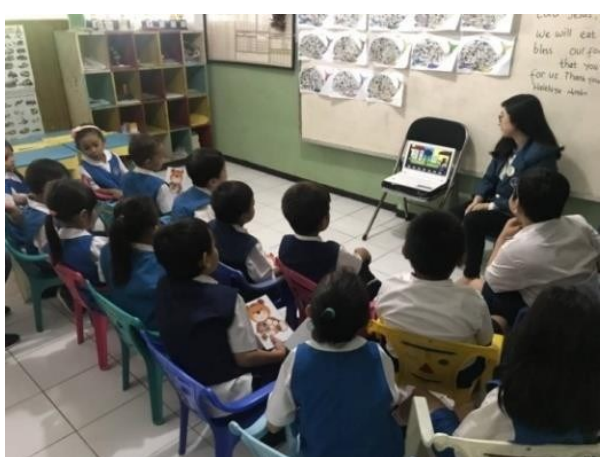

Gambar 4. Menonton video

Kegiatan menonton video ini berlangsung kurang lebih tiga puluh menit lamanya yang menampilkan lima video animasi. Video memiliki gambar visual dan juga audio yang dapat menarik siswa taman kanak-kanak untuk menyaksikan video tersebut yang tentunya memiliki pesan yang akan disampaikan. Begitu laptop dinyalakan siswa-siswa langsung berebut tempat untuk dapat duduk dibarisan terdepan sehingga bisa jelas menyaksikan video yang akan diputarkan. Siswa taman kanak- kanak sangat fokus melihat di layar laptop dan selalu aktif menjawab pertanyaan dari video yang diputarkan dengan suara yang kencang. Siswa taman kanak-kanak juga menunggu apa yang akan terjadi selanjutnya dalam video tersebut serta pesan yang disampaikan dalam setiap video akan mereka pahami. Hal ini dibuktikan dengan menjawab atau menceritakan kembali apa pesan ataupun isi dari video diakhir video yang dipandu oleh mahasiswa.

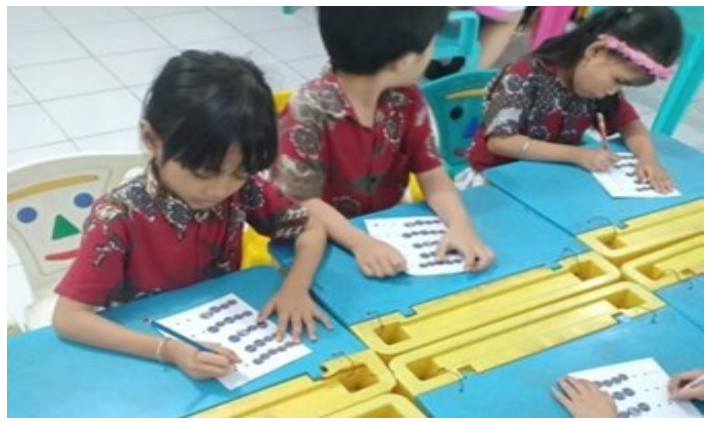

Gambar 4. Kartu semut

Kartu semut merupakan media dengan tujuan melakukan pengenalan mata uang dan belajar berhitung terhadap siswa taman kanak- kanak. Kegiatan ini memerlukan persiapan berupa kartu semut yang berisi koin-koin yang berbentuk seperti semut dan hasil penjumlahan. Kartu semut ini dimainkan dengan mencari pilihan jumlah yang sesuai dengan gambar yang ada dan akan dihubungkan menggunakan garis. Kegiatan ini merupakan kegiatan yang paling melelahkan dikarenakan banyak dari siswa taman kanak-kanak belum dapat menghitung dengan baik, maka disini mahasiswa sedikit tidak dapat mengatasi siswa taman kanakkanak yang terlihat dari jumlahnya yang sangat berbeda jauh.

Kegiatan berlangsung kurang lebih tiga puluh menit lamanya yang mendapatkan respon yang positif. Misalnya saja ada beberapa siswa taman kanak-kanak yang berani maju dan menghitung walaupun belum terlalu bisa menghitung dengan baik dan benar tetapi setidaknya siswa taman kanakkanak ini memiliki keberanian yang besar, karena jika dibandingkan dengan mahasiswa yang diminta untuk menjawab pertanyaan dari dosen atau menuliskan jawaban didepan pasti tidak ada yang mau berani maju padahal ada yang bisa mengerjakan soal tersebut.

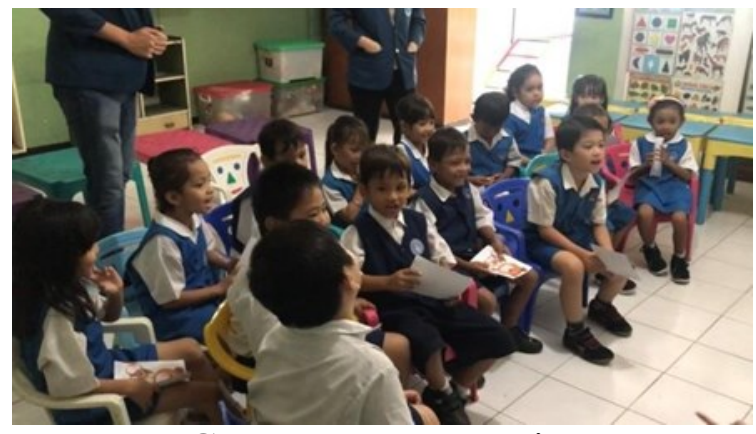

Gambar 5. Menyanyi

Menyanyi merupakan salah satu jenis seni dan juga merupakan bakat yang dapat dikembangkan sejak dini, maka kegiatan ini bertujuan untuk menggali potensi yang dimiliki oleh siswa taman kanak-kanak yang tidak disadari. Kegiatan ini memerlukan persiapan seperti lagu dan lirik lagu dikarenakan banyak dari siswa taman kanakkanak yang belum mengetahui lagu tersebut maka mahasiswa membantu dengan menyiapkan lirik lagu dan menuliskan pada papan tulis.

Awalnya kegiatan ini dimulai dengan mendengarkan lagu bersama dan juga menyanyikan lagu secara akapela agar suara siswa-siswi taman kanak-kanak dapat terdengar dengan jelas. Kegiatan menyanyi ini dapat dikatakan diluar dugaan karena 
disekolah kami melakukan pengabdian masyarakat ini anak-anaknya sedang dilatih bernyanyi lagu bahasa inggris dan saat mereka menunggu mahasiswa menuliskan lirik dan mempersiapkan lagu yang akan dibawakan ada beberapa anak yang bersenandung menyanyikan lagu yang diajarkan oleh guru-gurunya. Maka untuk mengisi kekosongan waktu dan dipandu oleh salah satu mahasiswa, siswa taman kanakkanak ini diajak bernyanyi lagu yang sedang mereka pelajari kemudian baru dilanjutkan lagu yang sudah disiapkan oleh mahasiswa.

Kegiatan ini merupakan kegiatan yang sangat digemari oleh siswa taman kanakkanak karena disini mereka dapat bernyanyi dengan suara yang keras. Hal ini juga merupakan bukti nyata semangat siswasiswi taman kanak-kanak untuk mengikuti setiap kegiatan dengan penuh semangat, walaupun banyak dari siswa-siswi taman kanak- kanak belum begitu menguasai lagu dan lirik lagunya tetapi mereka tetap menyanyikan dengan semangat.

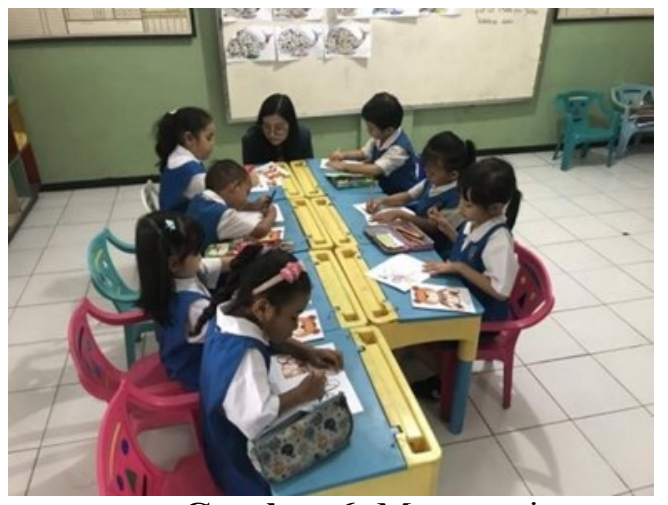

Gambar 6. Mewarnai

Kegiatan mewarnai merupakan salah satu kegiatan yang disukai oleh anak-anak dikarenakan kegiatan ini merupakan salah satu jenis seni yang dapat digunakan untuk mengekspresikan imajinasi yang dimiliki oleh anak-anak kedalam warna. Kegiatan ini sendiri memiliki persiapan seperti kertas yang dijilid dengan berisikan gambargambar yang dicetak hitam putih agar dapat diwarnai dengan imajinasi dari setiap siswasiswi taman kanak-kanak tidak hanya itu gambar tersebut juga memiliki unsur kepedulian seperti membantu orang tua membersihkan tempat tidur, membereskan mainan yang telah digunakan, dan masih banyak yang lainnya.

Kegiatan ini memakan waktu yang cukup lama yaitu sekitar satu jam dikarenakan gambar yang disediakan banyak dan juga siswa taman kanak-kanak senang mewarnai, maka siswa-siswi taman kanakkanak tidak akan berhenti mewarnai juga gambar yang disediakan sudah habis. Selain itu banyak siswa-siswi yang tidak memiliki pensil warna yang lengkap maka banyak siswa-siswi yang saling berebut, namun dari sini dapat dilihat banyak siswa-siswi yang rela meminjamkan pensil warnanya walaupun sang pemiliknya harus menunggu untuk menggunakan pensil warna tersebut. Dalam kegiatan ini sudah dapat dilihat bahwa ada beberapa anak yang memiliki rasa kepedulian yang lebih tinggi dibandingkan teman- temannya yang lain.

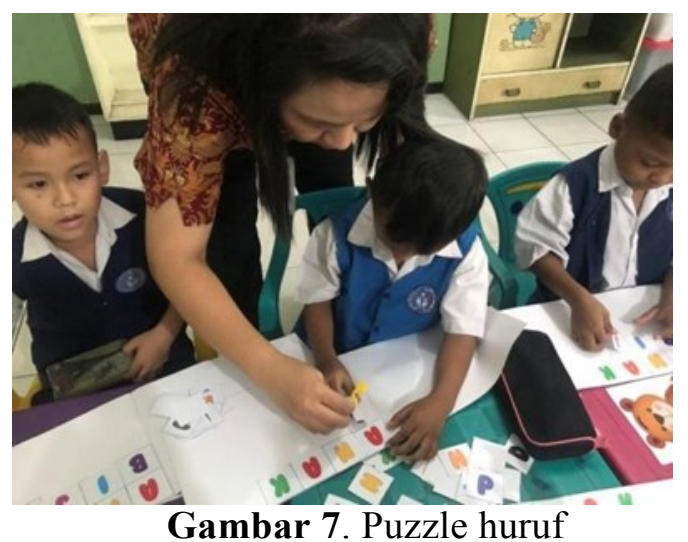

Kegiatan puzzle huruf ini dilakukan untuk meningkatkan daya ingat dan mengenalkan huruf terhadap siswa taman kanak-kanak. Dalam kegiatan ini memerlukan lem sebagai kunci utama agar kegiatan ini dapat berjalan dengan baik. Namun, mahasiswa hanya menyiapkan 3 buah lem sedangkan jumlah siswa taman kanak-kanak yaitu 20. Perbandingan ini merupakan suatu ujian bagi siswa taman kanak-kanak apakah bisa menahan ego dan saling menunggu giliran untuk menggunakan lem tersebut atau sebaliknya. Namun saat pelaksanaannya tidak semua siswa taman kanak- kanak mengedepankan ego mereka masing-masing, banyak diantaranya khususnya yang wanita lebih mengalah bahkan meminjamkan kepada teman yang lain yang selalu merebut lem. Dari sini dapat dikatakan bahwa siswa taman kanak-kanak telah memiliki rasa kepedulian, walaupun belum merata. Namun, hal ini perlu diapresiasi karena tidak semua orang bisa 
seperti ini walaupun orang yang lebih dewasa sekalipun terkadang masih memiliki ego yang tinggi terhadap dirinya sendiri dan melupakan orang lain.

Kegiatan tempel-menempel merupakan kegiatan yang sangat menyita banyak waktu dibandingkan kedua kegiatan yang lain. Kegiatan ini mendapatkan respon yang paling positif, karena dengan kegiatan ini mahasiswa bisa lebih mengetahui sifat dan karakteristik pada setiap siswa taman kanakkanak yang beranekaragam serta mahasiswa juga dituntut untuk memutar otak agar bisa menangani setiap siswa taman kanak-kanak dengan baik. Siswa taman kanak-kanak terlihat sangat bahagia yang terpancar dari senyum dan teriakan yang dilontarkan pada saat mahasiswa mengatakan bahwa hari ini akan melakukan kegiatan puzzle huruf yaitu menyusun atau menempel kertas yang bertuliskan huruf. Setelah itu siswa taman kanak-kanak juga menjadi siswa yang sangat aktif dan agresif dikarenakan ketersediaan lem yang sangat terbatas sehingga terjadi sedikit pertengkaran untuk memperebutkan lem dan perlombaan yang sangat sengit antara setiap siswa agar menjadi orang yang pertama menyelesaikan puzzle huruf.

Selagi menunggu siswa taman kanakkanak memilih dan menempel huruf yang dipandu oleh satu mahasiswa didepan serta dua mahasiswa yang berkeliling dan siap membantu siswa-siswi taman kanak-kanak yang terlihat kebingungan maupun kesusahan. Sementara itu satu mahasiswa bertugas mendokumentasikan kegiatan yang dilaksanakan baik mengambil gambar ataupun memvideokan. Akhir dari kunjungan video yang telah didokumentasikan selama kegiatan akan diputar untuk mengingatkan kembali bagaimana sikap dan kepedulian terhadap sesama teman atau kepada mahasiswa.

Tujuan dari keseluruhan aktivitas ini yaitu untuk memudahkan siswa taman kanak-kanak memahami tema yang diangkat pada kegiatan pengabdian masyarakat ini yaitu kepedulian, dimana dengan bekerja sama dan saling peduli, dapat melakukan banyak hal dan saling berguna satu dengan yang lainnya. Pemutaran dan pembuatan film pendek selama kegiatan berfungsi untuk mengenalkan teknologi kepada anakanak agar dapat dimanfaatkan secara positif bukan untuk sekedar kesenangan dan menghabiskan waktu. Pemberian contoh nyata tersebut, akan memotivasi siswa taman kanak-kanak untuk tetap mempertahankan kepeduliannya dan dapat tertanam dalam dirinya hingga dewasa nanti.

Tidak hanya memiliki manfaat bagi peserta yaitu siswa taman kanak-kanak, pengabdian masyarakat memiliki manfaat bagi mahasiswa sebagai penyelenggara kegiatan ini, mahasiswa mendapatkan pengalaman baru dalam menghadapi dan mengatasi berbagagai macam sikap dan sifat yang dimiliki oleh siswa taman kanak-kanak dengan berbagai macam karakter. Mahasiswa juga dapat menumbuhkan rasa kepedulian yang dapat diperlihatkan oleh siswa taman kanak-kanak dimana mereka terkadang lebih memiliki rasa kepedulian dan empati dibandingkan dengan mahasiswa karena kepolosan mereka. Dapat diketahui faktanya jika dilihat dari usia, mahasiswa tentu saja lebih tua dan diharapkan dapat berperilaku sebagaimana mestinya dibandingkan dengan siswa taman kanakkanak yang usianya jauh lebih muda, namun kedewasaan mahasiswa belum tentu tercermin dalam perilakunya sehari-hari sehingga kegiatan ini secara tidak langsung dapat menyadarkan mahasiswa untuk lebih memperdulikan sekitarnya baik orang lain yang memerlukan pertolongan ataupun hanya sekedar bertegur sapa dengan orang lain, mengucapkan kata tolong dan terima kasih, yang dibandingkan dengan hanya sibuk dengan pribadi masing-masing dan memainkan gadget sehingga mengabaikan semua hal yang ada disekitarnya.

\section{KESIMPULAN}

Pengabdian masyarakat merupakan salah satu kegiatan yang harus terus dilaksanakan dan dikembangkan pada kemajuan zaman yang begitu pesat ini, apa lagi dengan generasi milenial sekarang yang memiliki banyak ide-ide kreatif dan inovatif. Pengalaman yang didapat dengan mengikuti kegiatan pengabdian masyarakat yaitu bisa berinteraksi dengan kurun waktu yang cukup sering dalam 1-3 bulan bersama dengan siswa taman kanak-kanak dan juga bisa mengenali sifat dan karakteristik dari setiap siswa taman kanak-kanak yang sangat beragam mulai dari yang pendiam, manis, 
lucu, baik, hingga agresif dan tidak bisa diam. Selain itu juga dapat menyadarkan penyelanggara kegiatan bahwa banyak halhal yang masih perlu dikembangkan dalam rasa kepedulian yang dilihat langsung melalui siswa taman kanak- kanak yang memiliki rasa kepedulian yang tinggi kepada sesama dibandingkan mahasiswa. Semangat dan juga rasa menghargai orang lain yang dimiliki oleh siswa taman kanak-kanak yang menjadikan kegiatan ini bisa berjalan dengan baik adanya.Adanya keterbatasan waktu yang diberikan dari pihak peserta, dari sini dapat dikatakan bahwa masih belum adanya kesadaran tentang pentingnya pengabdian masyarakat dilingkungan sekitar.

Kegiatan pengabdian masyarakat ini bisa dilakukan untuk anak-anak usia dini agar pembelajaran yang telah didapat lebih melekat dalam diri anak-anak dan juga membawa pengaruh positif bagi kehidupan anak dimasa depan. Bagi penulis kegiatan ini juga memberikan dampak untuk lebih memahami sifat dan karakteristik setiap anak-anak, serta cara mememahami pribadi lain dan tidak hanya mementingkan diri sendiri yang pada masa kini hal itu kerap ditemukan. Kegiatan pengabdian masyarakat sebaiknya ditempuh oleh setiap mahasiswa dan diadakan secara rutin agar dapat memberi dampak yang konsisten terhadap perkembangan para siswa TK sebagai calon penerus bangsa.

\section{REFERENSI}

Avanth, S . 2018. Pentinya memiliki rasa peduli terhadap sesama. https://www.guesehat.com/ pentingnya- memiliki-rasa-peduli-terhadapsesama

Arsyad, A. 2011. Media Pembelajaran. PT Raja Grafindo Persada.Jakarta

Hurlock, E. B. (1980). Psikologi Perkembangan: Suatu Pendekatan Sepanjang Rentang Kehidupan. Erlangga.Jakarta

http://repository.petra.ac.id/18030/1/Publikasi1_89 001_4503.pdf

https://carapedia.com/pengertian_definisi_mahluk_s osial_menurut_para_ah li_info $960 . \mathrm{htm}$

Linawati, N. 2018. Meningkatkan Semangat Menabung Siswa TK Melalui media Kursi Cita-cita.

Usia Anak Bisa Masuk TK, SD, SMP dan SMA atau Sederajat 2018 Berdasarkan Pemendikbud No 14 Tahun 2018 https://www.rijal09.com/2018/05/usia- anakbisa-masuk-tk-sd-smp-dan-sma-atau- sederajat.html 